\title{
The roles of estrogen and estrogen receptors in gastrointestinal disease (Review)
}

\author{
CHANGMEI CHEN $^{1,2^{*}}$, XIANG GONG ${ }^{3 *}$, XIAOXU YANG ${ }^{1}$, XIANHUI SHANG ${ }^{4}$, \\ QIAN DU ${ }^{1}$, QIUSHI LIAO ${ }^{1}$, RUI XIE ${ }^{1}$, YUANSHOU CHEN $^{2}$ and JINGYU XU ${ }^{1,2}$ \\ ${ }^{1}$ Department of Gastroenterology, Affiliated Hospital of Zunyi Medical University; ${ }^{2}$ Department of Physiology, \\ Zunyi Medical University, Zunyi, Guizhou 563003; ${ }^{3}$ Institute of Burns, Tongren Hospital of Wuhan University, \\ Wuhan, Hubei 430060; ${ }^{4}$ Department of Pediatric Surgery, Affiliated Hospital of Zunyi Medical University, \\ Zunyi, Guizhou 563003, P.R. China
}

Received December 10, 2018; Accepted August 13, 2019

DOI: $10.3892 / \mathrm{ol} .2019 .10983$

\begin{abstract}
Estrogen is an important sex steroid hormone which serves an important role in the regulation of a number of biological functions, including regulating bone density, brain function, cholesterol mobilization, electrolyte balance, skin physiology, the cardiovascular system, the central nervous system and female reproductive organs. Estrogen exhibits various functions through binding to its specific receptors, estrogen receptor $\alpha$, estrogen receptor $\beta$ and $G$ protein-coupled estrogen receptor 1 . In recent years, researchers have demonstrated that estrogen and its receptors serve an important role in the gastrointestinal (GI) tract and contribute to the progression of a number of GI diseases, including gastroesophageal reflux, esophageal cancer, peptic ulcers, gastric cancer, inflammatory bowel disease, irritable bowel syndrome and colon cancer. The aim of this review is to provide an overview of estrogen and its receptors in GI disease, and highlight potential avenues for the prevention and treatment of GI diseases.
\end{abstract}

Correspondence to: Professor Jingyu $\mathrm{Xu}$, Department of Gastroenterology, Affiliated Hospital of Zunyi Medical University, 149 Dalian Road, Zunyi, Guizhou 563003, P.R. China

E-mail: xujingyu_gzzy@126.com

Professor Yuanshou Chen, Department of Physiology, Zunyi Medical University, 6 Xuefu West Road, Zunyi, Guizhou 563003, P.R. China E-mail: 807427393@qq.com

*Contributed equally

Key words: estrogen, estrogen receptors, estrogen receptor $\alpha$, estrogen receptor $\beta, \mathrm{G}$ protein-coupled estrogen receptor 1 , gastroesophageal reflux disease, esophageal cancer, peptic ulcer disease, gastric cancer, irritable bowel syndrome, inflammatory bowel disease, colon cancer

\section{Contents}

1. Introduction

2. Estrogen receptor

3. Estrogen and estrogen receptor in gastrointestinal disease

4. Conclusions

\section{Introduction}

Estrogens, including estrone, estriol and the biologically active metabolite $17 \beta$-estradiol (E2), have long been considered important regulators of female reproductive functions and are primarily produced in the ovaries. In addition to the ovaries, several extragonadal tissues, such as the mesenchymal cells in the adipose tissue of the breast, osteoblasts, chondrocytes, aortic smooth muscle cells, vascular endothelium and numerous parts of the brain also produce estrogens (1). Estrogens have been demonstrated to serve functions outside of the female reproductive system, including in the cardiovascular system and the central nervous system, and function to regulate bone density, brain function, cholesterol mobilization and electrolyte balance $(2,3)$. In contrast to women, men are largely dependent on the local synthesis of estrogens in extragonadal target tissues. This local production of estrogens encompasses the signaling modality from endocrine to paracrine, autocrine and intracrine signaling (4). Both estrogen and estrogen receptors have numerous effects on various organs and diseases specific to the gastrointestinal (GI) tract. For example, estrogen and estrogen receptors have been demonstrated to serve pathophysiological roles in gastroesophageal reflux disease, esophageal cancer, peptic ulcer disease, gastric cancer, irritable bowel syndrome, inflammatory bowel disease and colon cancer (5-7).

\section{Estrogen receptor}

The estrogen receptor has three subtypes; estrogen receptor $\alpha(E R \alpha)$, estrogen receptor $\beta$ (ER $\beta)$, which belong to nuclear receptors and membrane receptors, such as $\mathrm{G}$ protein-coupled 
estrogen receptor 1 (GPER1, also known as GPR30), which mediate all of estrogens effects, and the expression of each receptor is largely tissue-type specific (3) (Fig. 1).

$\mathrm{ER} \alpha$ and ER $\beta$ have similar structures, and were respectively identified and cloned in 1986 and 1996 (8). Both ERa and ER $\beta$ have distinct cellular distributions and regulate separate sets of genes (9). ER $\alpha$ is encoded by estrogen receptor 1 which is located on chromosome 6q25.1, and ER $\beta$ is encoded by estrogen receptor 2 or estrogen receptor 2 , which is located on chromosome 14q22-24 (10). ER $\alpha$ is primarily expressed in female sex organs, such as the breast, uterus and ovaries. $\mathrm{ER} \alpha$ has three known isoforms; two shorter ER $\alpha$ isoforms which lack the N-terminal domain, and a full-length ER $\alpha$ isoform. The truncated isoforms can heterodimerize with the full-length ER $\alpha$ isoform and repress ER $\alpha$ activity. ER $\beta$ is expressed in different types of tissues and cells, and to a higher degree in females compared with males (11). ER $\beta$ has at least five different isoforms; four shorter ER $\beta$ isoforms and a full-length ER $\beta$ isoform. The four shorter ER $\beta$ isoforms exhibit reduced ligand binding activity (12). The ER $\beta$ isoforms are neither homodimerizable nor transcriptionally active (12). However, they can preferentially dimerize with ER $\alpha$. The ER $\alpha$ and ER $\beta$ isoforms have different effects on estrogen signaling and target gene regulation (12) (Fig. 2).

GPER1 was first described in the 1990s (13) and it has been identified as one of the primary estrogen-sensitive receptors. Although GPER1 has a lower saturation, it possesses a high-affinity single binding site for estrogen, with a lower binding affinity for $17 \beta$-estradiol (14). The binding and decomposition of the receptor and its ligand are completed within a few minutes (15). GPER1 mediates estrogen-dependent rapid signaling events, independent of classical estrogen nuclear receptors (14). GPER1 activates multiple downstream signaling pathways, resulting in the activation of adenylate cyclase and increasing cyclic AMP levels, which promote intracellular calcium mobilization and synthesis of phosphatidylinositol 3,4,5-trisphosphate within the nucleus (16-18). GPER1 regulates a diverse range of biological processes, including bone and nervous system development, metabolism, cognition, male fertility and uterine function (19).

Although, ER $\alpha, E R \beta$ and GPER 1 possess a similar structure, they regulate divergent functions. In the present review, the role of estrogen and ERs in the physiology and pathology of the digestive system are explored.

\section{Estrogen and estrogen receptor in gastrointestinal disease}

\section{Estrogen and estrogen receptors in esophageal diseases}

Gastroesophageal reflux disease (GERD). GERD is a spectrum of reflux diseases of the gastroesophageal junction (20). GERD is a recurrent disease that has been defined in the Montreal Consensus Report as a chronic disease, in which the reflux of gastric contents into the esophagus in abnormal quantities causes clinical symptoms with or without mucosal erosions (21). GERD is influenced by multiple factors, including age, sex, and obesity, esophageal function (esophageal dysmotility), anatomical abnormalities (gastroesophageal hernias), Helicobacter pylori infection and environmental factors (including diet) (22). Epidemiological studies have shown that reflux esophagitis is more prevalent in males (23). Kim et al (5) found that men are more likely to develop GERD compared with that in women, and the prevalence of GERD in women is significantly increased with age, particularly in women $>50$ years old. It indicates that the prevalence of GERD is closely associated with sex differences and highlighting the potential involvement of estrogen. Asanuma et al (24) showed that the severity and the prevalence of GERD appear to be closely related to the reproductive hormone status of women. In the postmenopausal period, the prevalence of GERD rapidly increased, whereas it was lower compared with that in men in the reproductive period, which could be responsible for the increased prevalence of GERD in younger men compared with that in women, which reflects the level of the sex hormone estrogen. This potential effect of estrogen could delay the development of GERD via its anti-inflammatory function and acquisition of epithelial resistance in the esophagus against causative refluxate. Thus demonstrating that estrogen in women could be responsible for GERD being more common in men compared with that in women. In addition, Iijima and Shimosegawa (25) demonstrated the role of estrogen in attenuating the esophageal tissue damage in NO-related esophageal damage. Furthermore this research could explain the well-recognized male predominance in the GERD spectrum in humans. Moreover, in female rats, estrogen binds the estrogen receptor and attenuates esophageal tissue damage (26). Masaka et al (26) reached a similar conclusion from an acid-related reflux esophagitis model that was produced by surgical operation on male and female rats. Boeckxstaens et al (27) demonstrated that the increased prevalence and severity of reflux esophagitis in women is associated with reduced levels of estrogen after menopause. Together, these studies highlight the sex differences in the severity of esophageal mucosa damage in GERD in animal models, highlighting the role of estrogen in controlling GERD with the relevant esophageal epithelial tissue injury.

However, contradictory studies have shown that estrogen and estrogen receptor agonists are associated with an increased risk of gastroesophageal reflux disease symptoms (28-31). Female sex hormones can relax the lower esophageal sphincter and increase the risk of gastroesophageal reflux symptoms (32). Previously, it has been demonstrated that there is a positive correlation between gastroesophageal reflux symptoms and postmenopausal hormone replacement therapy (HRT) (31).

Furthermore, women whom have never taken postmenopausal hormone therapies, have a lower risk of reflux symptoms compared with women who have or are still taking estrogen replacement therapy (28). There is a positive correlation between the risk of reflux symptoms, increased estrogen dose and increased duration of estrogen use. Jacobson et al (28) showed an odds ratio of 1.39 for reflux symptoms that used a selective estrogen receptor modulator, and an odds ratio of 1.37 for women who used over-the-counter hormone preparations (28). Therefore, it is important to understand the role of estrogen and estrogen receptors in the pathogenesis of GERD.

Esophageal cancer $(E C)$. EC is one of the deadliest malignancies of the GI tract and causes $>400,000$ deaths each year. The two most common histological subtypes are esophageal adenocarcinoma (EAC) and esophageal squamous cell 


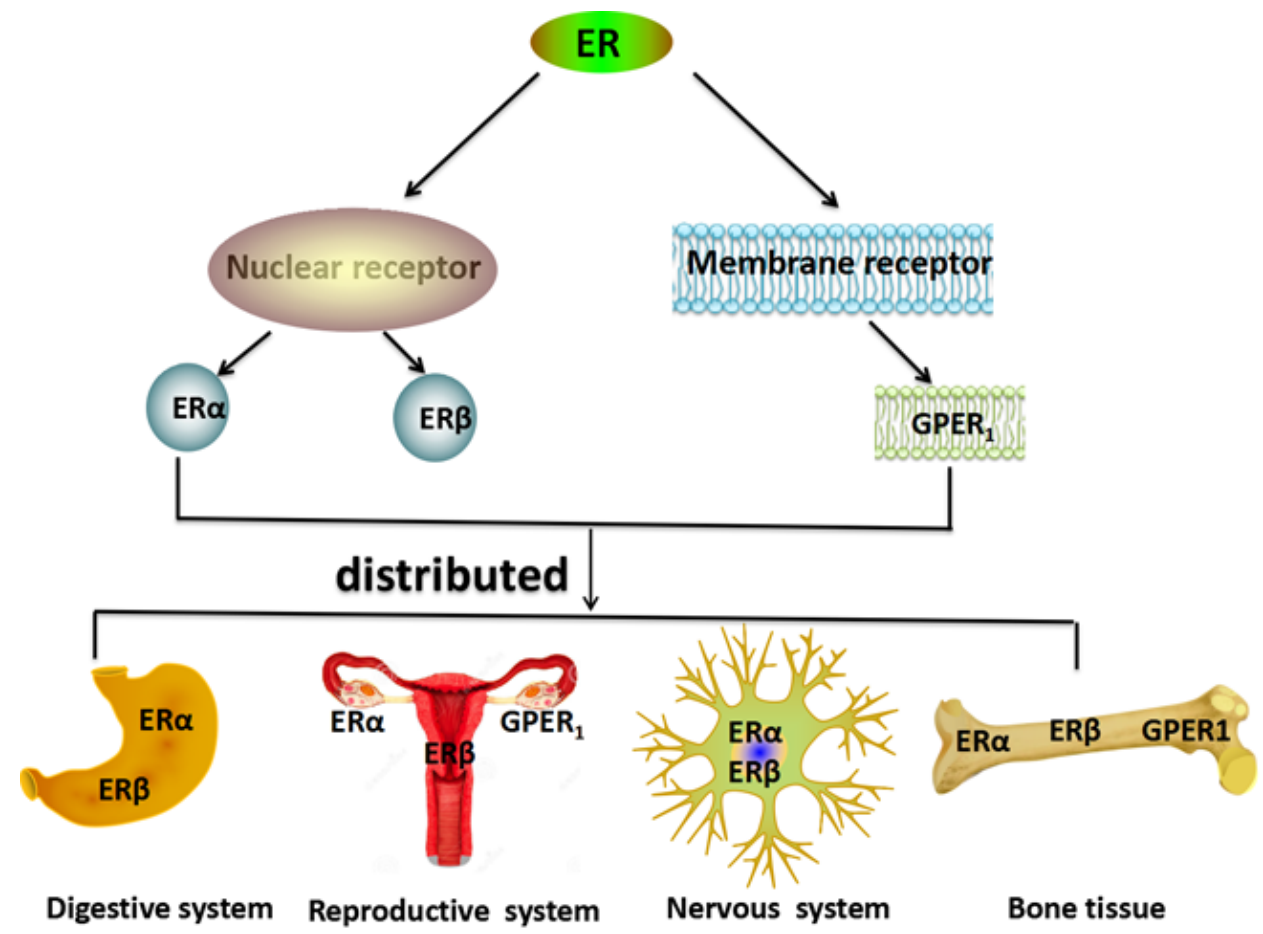

Figure 1. Distribution of estrogen and ERs in the human body. ERs include two broad categories: Nuclear receptors, which includes ER $\alpha$ and ER $\beta$ and membrane receptors, which includes GPER1. ER $\alpha$ and ER $\beta$ are primarily expressed in the digestive system and the nervous system.ER $\beta$, ER $\alpha$ and GPER 1 are primarily expressed in bone tissue and the reproductive system. GPER1, G protein-coupled estrogen receptor 1; ER, estrogen receptor.

carcinoma (ESCC) (33). The incidence of EAC was 6-10x lower in women compared with men, and that ESCC incidence was 2-3x lower (34). Mathieu et al (35) analyzed the prevalence of EC by histology and gender differences between 1973 and 2008 in nine population-related cancer studies, and the incidence of EAC increased in both males and females over this time period. Furthermore, the ratio of EAC in male vs. female was highest in individuals aged 50-54. The risk of EAC age-based incidence rate in postmenopausal females aged 80 increased significantly, and this trend was not seen in similarly aged males. Overall, estrogen-related endocrine milieu in premenopausal and perimenopausal females serves as a protective factor in the prevention of EAC, and with loss of estrogen in the body or an increase in time without estrogen-mediated maintenance, the prevalence of EAC incidence increases in older postmenopausal females. A total of 16 independent studies were analyzed by Wang et al (36), and the results showed that estrogen can lower the risk of EC. The relative risks were pooled and they showed a negative correlation between the risk of EC and hormone replacement therapy. In addition, menopausal women were at an increased risk of EAC compared with EC (36). The serum levels of estradiol in a healthy cohort from a high-incidence area (HIA) and a low-incidence area for esophageal cancer, as well as that of patients with ESCC from a HIA in Hena, China were assessed, and it showed that lower serum levels of estradiol were associated with a higher predisposition for developing ESCC (37). Furthermore, Zhang et al (38) demonstrated that $17 \beta-\mathrm{E} 2$, but not $17 \alpha-\mathrm{E} 2$, decreased proliferation of human ESCC cells in a dose-dependent manner, and this was attenuated by ICI1 82780 (an estrogen receptor antagonist). 17 $\beta$-E2 promotes intracellular calcium mobilization and extracellular calcium entry into ESCC cells, and estrogen exerted an antiproliferative effect on human ESCC cells, likely through an estrogen receptor-calcium signaling pathway. According to Hennessy et al (39), the antiproliferative effects of 17 $\beta$-E2 may occur through the ER $\beta$ estrogen receptor. Zuguchi et al (40) examined the expression status of both ER $\alpha$ and ER $\beta$ in 90 Japanese patients with ESCC and demonstrated that both ER $\alpha$ and ER $\beta$ were upregulated in ECGI-10 cells (an ESCC cell line). Additionally, the status of ER $\beta$ in ESCC was closely associated with unfavorable outcomes, possibly through increasing proliferation of carcinoma cells.

Taken together, these results indicate that estrogen and estrogen receptors inhibit growth of esophageal cancer by estradiol (41). Furthermore, estrogen replacement in postmenopausal women serves as a protective factor against esophageal cancer by reducing the degree of damage to esophageal tissues caused by gastric acid (42). Estrogen can reduce the risk of esophageal cancer. Therefore, a reduction or lack of estrogen may be an important factor in the high incidence of esophageal cancer in men and postmenopausal women.

\section{Estrogen and estrogen receptors in gastric diseases}

Peptic ulcers. Peptic ulcers include both gastric and duodenal ulcers, and complications include upper GI bleeding, GI perforation and gastric outlet obstruction (43). Peptic ulcer disease is a multifactorial and complex digestive disease, and its pathogenesis is unclear (44). Gastric protective factors include mucous, endogenous bicarbonate, prostaglandins and antioxidant agents; whereas, pepsin, gastric acid, bile acids and endogenous oxidant agents are recognized as risk factors that could cause damage to the stomach (45). Acid secretion, and the $\mathrm{pH}$ values of the stomach and duodenum did not differ 


\section{Two mechanisms of ER transcriptional activation}

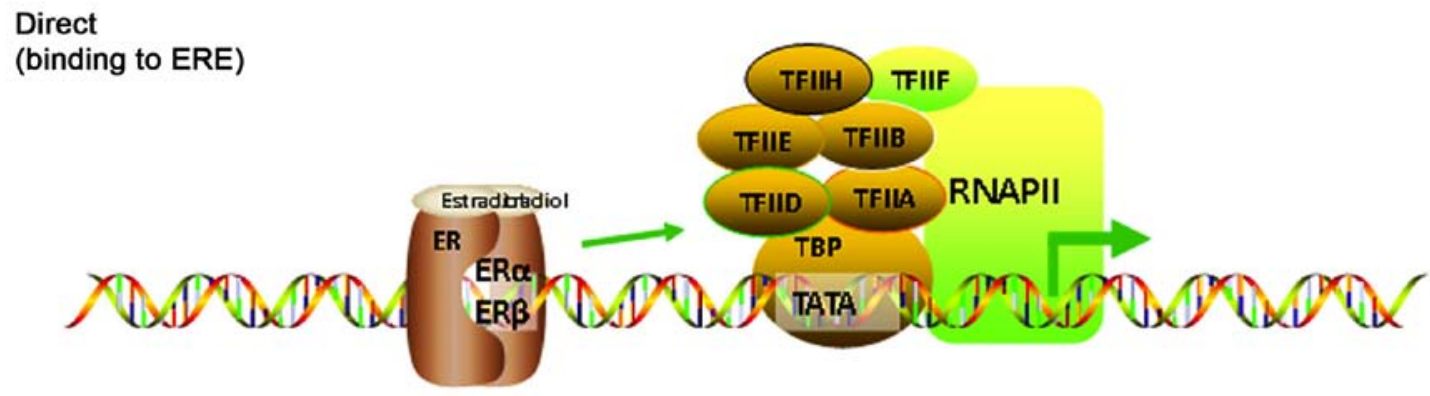

Indirect

(binding to other TF's)

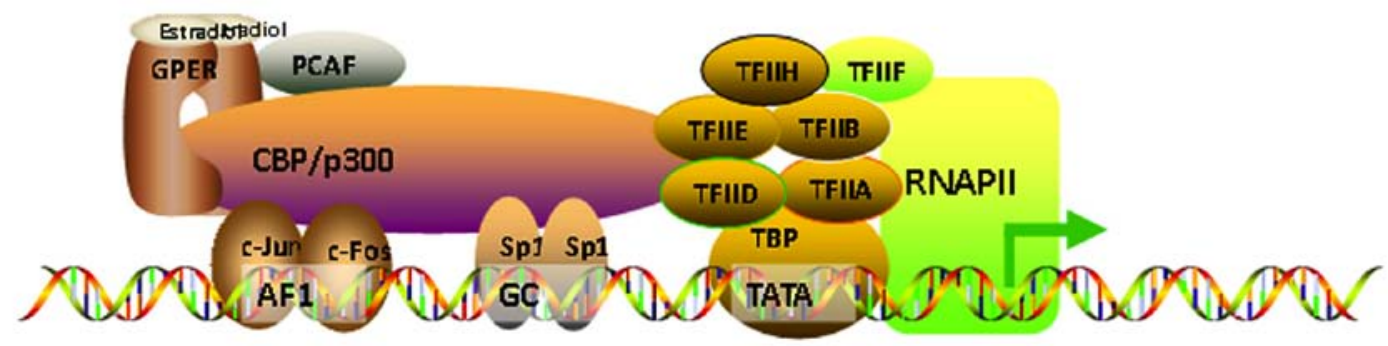

Figure 2. Mechanisms of estrogen signaling. Direct pathway: When estrogen binds to the nuclear receptor, it forms an estrogen-receptor complex, which changes the conformation of the receptor, forming a dipolymer and exposing the DNA binding region. The complex enters the nucleus through the nuclear pore in the form of a dipolymer. Activated ER $\alpha / \beta$ can directly combine with ERE and subsequently interacts with the target gene or with other transcription factors, forming a complex, which promotes activity of regulatory proteins located at the promoter sites of target genes. This results in an increase in the mRNA expression and thus potentially protein expression levels of the target gene. Indirect pathway: GPER is rapidly activated by intracellular PCAF combining with estrogen-like substances. Activated GPER directly associates with CBP/P300 and interacts with the target gene or with other transcription factors, forming complexes such as the proto-oncogene Fos/jun and SP-1, which promotes activity of regulatory proteins located at the promoter sites of target genes. ER, estrogen receptor; GPER, G protein-coupled estrogen receptor; $\mathrm{CBP} / \mathrm{P} 300$, transcription complex auxiliary activation factor; PCAF, P300/CBP-related factors; ERE, estrogen response element.

between males and females (46). Peptic ulcers are relatively rare during pregnancy, and estrogen exhibits a protective effect against the incidence and severity of peptic ulcers, and the risk of ulcers is lower in women compared with men $(6,47)$. Okada et al (48) found that individuals $>70$ years in age, had an increased prevalence of ulcers and this was also true in postmenopausal women. The decrease in the serum levels of estrogen induced a reduction in gastric mucosal defenses. Additionally, another study suggested that estrogen exerts an antioxidant effect, which directly scavenges free oxygen radicals, activates antioxidant enzymes, represses the production of superoxides and reduces the formation of peptic ulcers (49).

Therefore, estrogen exhibits a protective effect from peptic ulcers, which may be achieved through its antioxidant effects. However, the specific mechanisms underlying its protective effects require further study.

Gastric cancer $(G C)$. GC is a malignant tumor and the fifth highest incidence and third highest mortality rates in the world (50). Epidemiological studies have suggested that the prevalence of gastric cancer is higher in men than women with a ratio of 1.2:1.0 male:female. However, the differences between male and females becomes negligible when compared with postmenopausal women (51). Tokunaga et al (52) first reported the relationship between hormone receptors and $\mathrm{GC}$, and they highlighted the fact that estrogens may serve a protective role against gastric cancer. Lindblad et al (53) found that the probability of developing gastric cancer was not increased in patients with prostate cancer. In addition, Furukawa et al (54) found that female, castrated male and estrogen-treated male rats had a lower incidence of gastric cancer with lower histological differentiation compared with that in non-treated male rats after administration of the carcinogen, N-methyl-N0-nitro-N-nitrosoguanidine, and untreated male rats had increased rates of morbidity as a result of gastric cancer compared with castrated or estrogen-treated male rats.

The expression of ER $\alpha$ and ER $\beta$ in gastric cancer has been previously demonstrated (55). It has been hypothesized that ERs serve an important role in the occurrence and development of gastric cancer (56). Studies have demonstrated that ER $\beta$, but not $\mathrm{ER} \alpha$, is abundantly expressed in GC (57-61). However, other researchers have demonstrated the expression of both receptors in GC (62-64). Zhou et al (65) found that the expression of $\beta$-catenin was reduced when ER $\alpha$ was overexpressed, and this resulted in a decrease in growth and proliferation of GC cells, and an increase in the apoptotic rate by preventing entry into the $\mathrm{G}_{1} / \mathrm{G}_{0}$ phase. ER- $\alpha$ is considered a rare subtype of estrogen receptor ER $\alpha$, which is associated with increased 


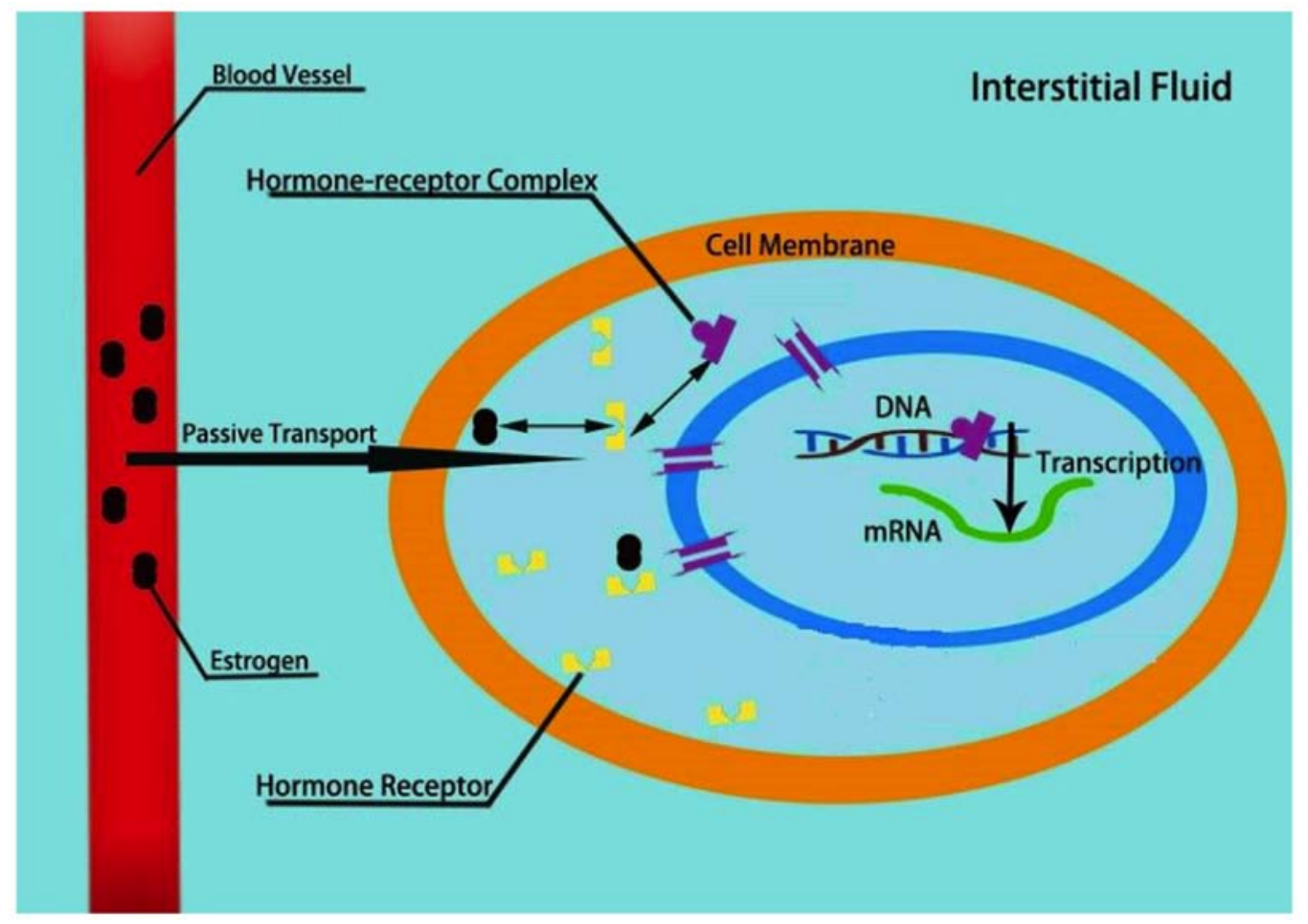

Figure 3. Estrogen and the estrogen receptor-mediated signaling pathway. Estrogen is transported into the cell and combines with the estrogen receptor, forming a hormone-receptor complex. The combined complex enters the nucleus, and regulates the transcription process as described in Fig. 2. Nuclear estrogen receptor is a transcription factor that regulates the function of estrogen complexes and can modulate gene expression by interacting with other proteins and receptors.

lymph node metastasis and invasion in GC. Non-genomic estrogen signaling mediated by ER- $\alpha$ was involved in the c-Src signaling pathway in SGC7901 GC cells (66). A recent study found that ER $\alpha$ expression in gastric cancer cells was increased by low concentrations of $17 \beta$-estradiol, which in turn resulted in increased proliferation by activating mitogen-activated protein kinase signaling pathway (67). In addition, knock down of ER $\alpha$ did not affect the proliferation, migration and invasion of gastric cancer cells (67). Compared with expression of $\mathrm{ER} \alpha$, expression of $\mathrm{ER} \beta$ in noncancerous tissues was significantly higher in female rats compared with male rats (68). Ryu et al (61) evaluated the presence of ER $\beta$ in gastric cancer and showed that ER $\beta$ was likely not a contributing factor for the invasiveness of gastric cancer.

Therefore, investigating the roles and mechanisms of ER and its receptors may highlight potential mechanisms to improve management of the disease (Fig. 3).

\section{Estrogen and estrogen receptors in intestinal diseases}

Irritable bowel syndrome (IBS). Irritable bowel syndrome is one of the most common GI disorders, and is typically characterized by disorderly bowel movements and chronic abdominal pain (69). Based on epidemiological studies (70-72), irritable bowel syndrome is more prevalent in women than men, with a ratio range of $2-4: 1$, highlighting the possibility of the involvement of estrogen serving a role in the pathophysiology of IBS (7). IBS symptoms were determined to be associated with hormonal status, and the role of sex steroid hormones in the pathophysiology of IBS is gaining increasing attention (73). Studies have demonstrated that estrogen participates in modulating visceral sensitivity and regulating motor and sensory functions in IBS animal models (74,75). Additionally, Jacenik et al (76) determined the estrogen receptor engagement in the IBS subtypes, constipation predominant IBS and diarrhea predominant IBS (IBS-D). The authors analyzed whether estrogen signaling was accompanied by alterations in the expression of pro-inflammatory and anti-inflammatory cytokines and microRNAs, which regulate genes associated with the immune response. Both ER $\alpha$ and GPER expression were upregulated in IBS. There was a correlation between the expression of GPER in patients with IBS-D and the severity of abdominal pain, and an association between the GPER-mediated estrogenic effects on IBS pathogenesis and activation of mast cells in the colon, thus highlighting a novel avenue for understanding the pathogenesis of sex differences in IBS (77). GPER-mediated estrogenic effects were involved in the regulation of visceral pain and GI motility (78).

Inflammatory bowel disease (IBD). IBD is an intestinal inflammatory disease, which is incompletely understood. There is a lack of clear understanding of the pathogenesis of IBD and established effective treatments (79). Previously, patients with IBD were diagnosed primarily in North America and Europe (80). As lifestyle, environment and diets of individuals has changed overtime, the prevalence of IBD has increased worldwide, particularly in children and adult populations (81). IBD includes both ulcerative colitis (UC) and Crohn's disease (CD). The differences in cancer risk between male and female mice were evaluated for patients with IBD, and the results showed that IBD conferred a higher risk of developing colorectal cancer (CRC) in males compared with females. Colitis is hypothesized to be associated with the development of IBD (82). 
ER $\beta$ is the predominant ER subtype expressed in colon tissues, and it maintains a normal epithelial architecture protecting against chronic colitis (83-85). Men present with a higher risk of developing colitis than women, implicating estrogen as a protective factor against developing colitis. Armstrong et al (86) found that E2 treatment reduced inflammation in the colon in control mice. The expression of interleukins (ILs; particularly IL-6, IL-12 and IL-17), granulocyte-macrophage colony-stimulating factor, interferon- $\gamma$, monocyte chemotactic proteins-1, macrophage inflammatory protein- $1 \alpha$ and tumor necrosis factor- $\alpha$ were not significantly increased in control mice following treatment with E2. The extent of damage was higher in the control ER $\beta$ knockout mice compared with the E2-treated ER $\beta$ knockout mice. Additionally, ER $\beta$ mRNA expression levels were decreased in a colitis mouse model of intestinal inflammation (87). ER $\beta$ knockout mice presented with colitis of increased severity compared with the wild-type group (88). Therefore, E2 may protect against acute colitis through the activation of ER $\beta$.

Colon cancer. Colon cancer is one of the most common types of malignant tumor of the GI tract and the second leading cause of cancer-associated death worldwide. An epidemiological study of colon cancer prevalence found that females exhibited a higher prevalence of colon cancer. However, women aged 18-44 with colon cancer had an improved prognosis compared with men of the same age and women $>50$ years (89). Upregulated expression of ER $\beta 1$ in colon cancer is associated with an improved survival outcome (90). Similarly, downregulated expression of ER $\beta 1$ is associated with poorer survival outcome (90). Numerous studies have demonstrated that hormone replacement therapy (HRT) in postmenopausal women did not serve a protective role $(91,92)$, contradicting previous studies $(93,94)$. The Women's Health Initiative showed that the prevalence of colon cancer decreased by $30 \%$ following treatment with HRT in postmenopausal women (95).

Interestingly, Bustos et al (89) found that estrogen receptors (ER $\alpha$ and GPER) are activated by $17 \beta-E 2$ under anoxic conditions, when ERb expression was reduced/absent in patients with colon cancer. An E2-related gene (ataxia telangiectasia mutated) was inhibited in anoxic conditions through GPER signaling.

E2 treatment reinforced hypoxia-associated migration and proliferation of colon cancer cells, whereas in an aerobic environment, cell migration and proliferation were decreased by E2 treatment (89). The effects of E2 on the cellular responses in an aerobic environment and anoxic conditions were mediated by GPER. Therefore, in order to fully predict the estrogenic response in patients with colon cancer, it is necessary to understand not only the status of estrogen receptor expression in tumor cells, but also the aerobic/anoxic conditions of the local tumor microenvironment (89).

\section{Conclusions}

Estrogen is a sex hormone that regulates the development and function of the reproductive systems in all mammalian species, and increasing evidence demonstrates the multifaceted nature of its effects on non-reproductive organs during physiological and pathophysiological conditions. Understanding the effects of estrogen and estrogen receptor function may provide an important theoretical basis for improving clinical treatments of GI disease.

\section{Acknowledgements}

The authors would like to thank Professor Biguang Tuo (Department of Gastroenterology, Affiliated Hospital to Zunyi Medical University) for suggestions for the manuscript.

\section{Funding}

This study was supported by research grants from the National Natural Science Foundation of China (grant nos. 81660099 and 81770610).

\section{Availability of data and materials}

Data sharing is not applicable to the present study, as no datasets were generated or analyzed during the current study.

\section{Authors' contributions}

CMC, XG, XXY, XHS, QD, QSL and RX conceived, wrote and revised the paper. YSC and JYX wrote and revised the paper. All authors approved the final version of the manuscript for submission.

\section{Ethics approval and consent to participate}

Not applicable.

\section{Patient consent for publication}

Not applicable.

\section{Competing interests}

The authors declare that they have no competing interests.

\section{References}

1. Simpson ER: Sources of estrogen and their importance. J Steroid Biochem Mol Biol 86: 225-230, 2003.

2. Guyton AC and Hall J: Guyton and Hall Textbook of Medical Physiology. pp 957-999, 2011.

3. Nilsson S and Gustafsson JA: Estrogen receptors: Therapies targeted to receptor subtypes. Clin Pharmacol Ther 89: 44-55, 2011.

4. Labrie F: Extragonadal synthesis of sex steroids: Intracrinology. Ann Endocrinol (Paris) 64: 95-107, 2003.

5. Kim YS, Kim N and Kim GH: Sex and gender differences in gastroesophageal reflux disease. J Neurogastroenterol Motil 22: 575-588, 2016.

6. Kurt D, Saruhan BG, Kanay Z, Yokus B, Kanay BE, Unver O and Hatipoglu S: Effect of ovariectomy and female sex hormones administration upon gastric ulceration induced by cold and immobility restraint stress. Saudi Med J 28: 1021-1027, 2007.

7. Meleine $M$ and Matricon J: Gender-related differences in irritable bowel syndrome: Potential mechanisms of sex hormones. World J Gastroenterol 20: 6725-6743, 2014.

8. Batistatou A, Stefanou D, Goussia A, Arkoumani E, Papavassiliou AG and Agnantis NJ: Estrogen receptor beta (ERbeta) is expressed in brain astrocytic tumors and declines with dedifferentiation of the neoplasm. J Cancer Res Clin Oncol 130: 405-410, 2004. 
9. Yang H, Sukocheva OA, Hussey DJ and Watson DI: Estrogen, male dominance and esophageal adenocarcinoma: Is there a link? World J Gastroenterol 18: 393-400, 2012.

10. Enmark E, Pelto-Huikko M, Grandien K, Lagercrantz S, Lagercrantz J, Fried G, Nordenskjold $M$ and Gustafsson JA: Human estrogen receptor beta-gene structure, chromosomal localization, and expression pattern. J Clin Endocrinol Metab 82: 4258-4265, 1997.

11. Rochira V, Granata AR, Madeo B, Zirilli L, Rossi G and Carani C: Estrogens in males: What have we learned in the last 10 years? Asian J Androl 7: 3-20, 2005.

12. Heldring N, Pike A, Andersson S, Matthews J, Cheng G Hartman J, Tujague M, Strom A, Treuter E, Warner M and Gustafsson JA: Estrogen receptors: How do they signal and what are their targets. Physiol Rev 87: 905-931, 2007.

13. Carmeci C, Thompson DA, Ring HZ, Francke U and Weigel RJ: Identification of a gene (GPR30) with homology to the G-protein-coupled receptor superfamily associated with estrogen receptor expression in breast cancer. Genomics 45: 607-617, 1997.

14. Filardo EJ and Thomas P: Minireview: G protein-coupled estrogen receptor-1, GPER-1: Its mechanism of action and role in female reproductive cancer, renal and vascular physiology. Endocrinology 153: 2953-2962, 2012.

15. Sanden C, Broselid S, Cornmark L, Andersson K Daszkiewicz-Nilsson J, Martensson UE, Olde B and Leeb-Lundberg LM: G protein-coupled estrogen receptor 1/G protein-coupled receptor 30 localizes in the plasma membrane and traffics intracellularly on cytokeratin intermediate filaments. Mol Pharmacol 79: 400-410, 2011.

16. Filardo EJ, Quinn JA, Bland KI and Frackelton AR Jr: Estrogen-induced activation of Erk-1 and Erk-2 requires the $\mathrm{G}$ protein-coupled receptor homolog, GPR30, and occurs via trans-activation of the epidermal growth factor receptor through release of HB-EGF. Mol Endocrinol 14: 1649-1660, 2000

17. Revankar CM, Cimino DF, Sklar LA, Arterburn JB and Prossnitz ER: A transmembrane intracellular estrogen receptor mediates rapid cell signaling. Science 307: 1625-1630, 2005.

18. Thomas P, Pang Y, Filardo EJ and Dong J: Identity of an estrogen membrane receptor coupled to a $\mathrm{G}$ protein in human breast cancer cells. Endocrinology 146: 624-632, 2005.

19. Sharma G and Prossnitz ER: G-protein-coupled estrogen receptor (GPER) and sex-specific metabolic homeostasis. Adv Exp Med Boil 1043: 427-453, 2017.

20. Vakil N, van Zanten SV, Kahrilas P, Dent J and Jones R; Globale Konsensusgruppe: The Montreal definition and classification of gastroesophageal reflux disease: A global, evidence-based consensus paper. Z Gastroenterol 45: 1125-1140, 2007 (Article in German)

21. Katzka DA, Pandolfino JE and Kahrilas PJ: Phenotypes of gastroesophageal reflux disease: Where rome, lyon, and montreal meet Clin Gastroenterol Hepatol July 15, 2019 (Epub ahead of print).

22. Nam SY, Choi IJ, Ryu KH, Park BJ, Kim YW, Kim HB and Kim JS: The effect of abdominal visceral fat, circulating inflammatory cytokines, and leptin levels on reflux esophagitis. J Neurogastroenterol Motil 21: 247-254, 2015.

23. Pohl H, Wrobel K, Bojarski C, Voderholzer W, Sonnenberg A, Rosch T and Baumgart DC: Risk factors in the development of esophageal adenocarcinoma. Am J Gastroenterol 108: 200-207, 2013.

24. Asanuma K, Iijima K and Shimosegawa T: Gender difference in gastro-esophageal reflux diseases. World J Gastroenterol 22 : $1800-1810,2016$.

25. Iijima $\mathrm{K}$ and Shimosegawa $\mathrm{T}$ : Involvement of luminal nitric oxide in the pathogenesis of the gastroesophageal reflux disease spectrum. J Gastroenterol Hepatol 29: 898-905, 2014.

26. Masaka T, Iijima K, Endo H, Asanuma K, Ara N, Ishiyama F, Asano N, Koike T, Imatani A and Shimosegawa T: Gender differences in oesophageal mucosal injury in a reflux oesophagitis model of rats. Gut 62: 6-14, 2013.

27. Boeckxstaens G, El-Serag HB, Smout AJ and Kahrilas PJ: Symptomatic reflux disease: The present, the past and the future. Gut 63: 1185-1193, 2014.

28. Jacobson BC, Moy B, Colditz GA and Fuchs CS: Postmenopausal hormone use and symptoms of gastroesophageal reflux. Arch Intern Med 168: 1798-1804, 2008.

29. Van Thiel DH, Gavaler JS and Stremple J: Lower esophageal sphincter pressure in women using sequential oral contraceptives. Gastroenterology 71: 232-234, 1976.

30. Nilsson M, Lundegardh G, Carling L, Ye W and Lagergren J: Body mass and reflux oesophagitis: An oestrogen-dependent association? Scand J Gastroenterol 37: 626-630, 2002.
31. Nilsson M, Johnsen R, Ye W, Hveem K and Lagergren J: Obesity and estrogen as risk factors for gastroesophageal reflux symptoms. JAMA 290: 66-72, 2003.

32. Nordenstedt H, Zheng Z, Cameron AJ, Ye W, Pedersen NL and Lagergren J: Postmenopausal hormone therapy as a risk factor for gastroesophageal reflux symptoms among female twins. Gastroenterology 134: 921-928, 2008.

33. el-Serag HB: The epidemic of esophageal adenocarcinoma. Gastroenterol Clin North Am 31: 421-440, viii, 2002.

34. Vizcaino AP, Moreno V, Lambert R and Parkin DM: Time trends incidence of both major histologic types of esophageal carcinomas in selected countries, 1973-1995. Int J Cancer 99: 860-868, 2002.

35. Mathieu LN, Kanarek NF, Tsai HL, Rudin CM and Brock MV: Age and sex differences in the incidence of esophageal adenocarcinoma: Results from the surveillance, epidemiology, and end results (SEER) registry (1973-2008). Dis Esophagus 27: 757-763, 2014.

36. Wang BJ, Zhang B, Yan SS, Li ZC, Jiang T, Hua CJ, Lu L, Liu XZ, Zhang DH, Zhang RS and Wang $\mathrm{X}$ : Hormonal and reproductive factors and risk of esophageal cancer in women: A meta-analysis. Dis Esophagus 29: 448-454, 2016.

37. Wang QM, Qi YJ, Jiang Q, Ma YF and Wang LD: Relevance of serum estradiol and estrogen receptor beta expression from a high-incidence area for esophageal squamous cell carcinoma in China. Med Oncol 28: 188-193, 2011.

38. Zhang Z, He Q, Fu S and Zheng Z: Estrogen receptors in regulating cell proliferation of esophageal squamous cell carcinoma: Involvement of intracellular $\mathrm{Ca}(2+)$ signaling. Pathol Oncol Res 23: 329-334, 2017.

39. Hennessy BA, Harvey BJ and Healy V: 17beta-Estradiol rapidly stimulates c-fos expression via the MAPK pathway in T84 cells. Mol Cell Endocrinol 229: 39-47, 2005.

40. Zuguchi M, Miki Y, Onodera Y, Fujishima F, Takeyama D, Okamoto H, Miyata G, Sato A, Satomi S and Sasano H: Estrogen receptor $\alpha$ and $\beta$ in esophageal squamous cell carcinoma. Cancer Sci 103: 1348-1355, 2012.

41. Ueo H, Matsuoka H, Sugimachi K, Kuwano H, Mori M and Akiyoshi T: Inhibitory effects of estrogen on the growth of a human esophageal carcinoma cell line. Cancer Res 50: 7212-7215, 1990

42. Menon S, Nightingale $P$ and Trudgill N: Is hormone replacement therapy in post-menopausal women associated with a reduced risk of oesophageal cancer? United European Gastroenterol J 2: 374-382, 2014.

43. Lanas A and Chan FKL: Peptic ulcer disease. Lancet 390: 613-624, 2017.

44. Kanotra R, Ahmed M, Patel N, Thakkar B, Solanki S, Tareen S, Fasullo MJ, Kesavan M, Nalluri N, Khan A, et al: Seasonal variations and trends in hospitalization for peptic ulcer disease in the United States: A 12-year analysis of the nationwide inpatient sample. Cureus 8: e854, 2016.

45. Suleyman H, Albayrak A, Bilici M, Cadirci E and Halici Z Different mechanisms in formation and prevention of indomethacin-induced gastric ulcers. Inflammation 33: 224-234, 2010.

46. Feldman M, Richardson CT and Walsh JH: Sex-related differences in gastrin release and parietal cell sensitivity to gastrin in healthy human beings. J Clin Invest 71: 715-720, 1983.

47. Sangma TK, Jain S and Mediratta PK: Effect of ovarian sex hormones on non-steroidal anti-inflammatory drug-induced gastric lesions in female rats. Indian J Pharmacol 46: 113-116, 2014.

48. Okada K, Inamori M, Imajyo K, Chiba H, Nonaka T, Shiba T, Sakaguchi T, Atsukawa K, Takahashi H, Hoshino E and Nakajima A: Gender differences of low-dose aspirin-associated gastroduodenal ulcer in Japanese patients. World J Gastroenterol 16: 1896-1900, 2010.

49. Speir E, Yu ZX, Takeda K, Ferrans VJ and Cannon RO III: Antioxidant effect of estrogen on cytomegalovirus-induced gene expression in coronary artery smooth muscle cells. Circulation 102: 2990-2996, 2000.

50. Jiang $F$ and Shen $X$ : Current prevalence status of gastric cancer and recent studies on the roles of circular RNAs and methods used to investigate circular RNAs. Cell Mol Biol Lett 24: 53, 2019.

51. Chung HW, Noh SH and Lim JB: Analysis of demographic characteristics in 3242 young age gastric cancer patients in Korea. World J Gastroenterol 16: 256-263, 2010.

52. Tokunaga A, Kojima N, Andoh T, Matsukura N, Yoshiyasu M, Tanaka N, Ohkawa K, Shirota A, Asano G and Hayashi K: Hormone receptors in gastric cancer. Eur J Cancer Clin Oncol 19: 687-689, 1983 . 
53. Lindblad M, Ye W, Rubio C and Lagergren J: Estrogen and risk of gastric cancer: A protective effect in a nationwide cohort study of patients with prostate cancer in Sweden. Cancer Epidemiology Biomarkers Prev 13: 2203-2207, 2004.

54. Furukawa H, Iwanaga T, Koyama $H$ and Taniguchi $\mathrm{H}$ : Effect of sex hormones on the experimental induction of cancer in rat stomach-a preliminary study. Digestion 23: 151-155, 1982.

55. Kim MJ, Cho SI, Lee KO, Han HJ, Song TJ and Park SH: Effects of $17 \beta$-estradiol and estrogen receptor antagonists on the proliferation of gastric cancer cell lines. J Gastric Cancer 13: 172-178, 2013.

56. Chandanos E and Lagergren J: Oestrogen and the enigmatic male predominance of gastric cancer. Eur J Cancer 44: 2397-2403, 2008.

57. Sunakawa Y, Cao S, Berger MD, Matsusaka S, Yang D, Zhang W, Ning Y, Parekh A, Stremitzer S, Mendez A, et al: Estrogen receptor-beta genetic variations and overall survival in patients with locally advanced gastric cancer. Pharmacogenomics J 17: 36-41, 2017.

58. Matsuyama S, Ohkura Y, Eguchi H, Kobayashi Y, Akagi K, Uchida K, Nakachi K, Gustafsson JA and Hayashi S: Estrogen receptor beta is expressed in human stomach adenocarcinoma. J Cancer Res Clin Oncol 128: 319-324, 2002

59. Takano N, Iizuka N, Hazama S, Yoshino S, Tangoku A and Oka M: Expression of estrogen receptor-alpha and -beta mRNAs in human gastric cancer. Cancer Lett 176: 129-135, 2002.

60. Wang M, Pan JY, Song GR, Chen HB, An LJ and Qu SX: Altered expression of estrogen receptor alpha and beta in advanced gastric adenocarcinoma: Correlation with prothymosin alpha and clinicopathological parameters. Eur J Surg Oncol 33: 195-201, 2007.

61. Ryu WS, Kim JH, Jang YJ, Park SS, Um JW, Park SH, Kim SJ Mok YJ and Kim CS: Expression of estrogen receptors in gastric cancer and their clinical significance. J Surg Oncol 106: 456-461, 2012.

62. Qin J, Liu M, Ding Q, Ji X, Hao Y, Wu X and Xiong J: The direct effect of estrogen on cell viability and apoptosis in human gastric cancer cells. Mol Cell Biochem 395: 99-107, 2014.

63. Zhang BG, Du T, Zang MD, Chang Q, Fan ZY, Li JF, Yu BQ, $\mathrm{Su} \mathrm{LP}$, Li C, Yan C, et al: Androgen receptor promotes gastric cancer cell migration and invasion via AKT-phosphorylation dependent upregulation of matrix metalloproteinase 9 . Oncotarget 5: 10584-10595, 2014.

64. Wesolowska M, Pawlik P and Jagodzinski PP: The clinicopathologic significance of estrogen receptors in human gastric carcinoma. Biomed Pharmacother 83: 314-322, 2016.

65. Zhou J, Teng R, Xu C, Wang Q, Guo J, Xu C, Li Z, Xie S, Shen J and Wang L: Overexpression of ER $\alpha$ inhibits proliferation and invasion of MKN28 gastric cancer cells by suppressing $\beta$-catenin. Oncol Rep 30: 1622-1630, 2013.

66. Wang X, Deng H, Zou F, Fu Z, Chen Y, Wang Z and Liu L: ER-a36-mediated gastric cancer cell proliferation via the c-Src pathway. Oncol Lett 6: 329-335, 2013.

67. Tang W, Liu R, Yan Y, Pan X, Wang M, Han X, Ren H and Zhang Z: Expression of estrogen receptors and androgen receptor and their clinical significance in gastric cancer. Oncotarget 8 40765-40777, 2017.

68. Wakui S, Motohashi M, Muto T, Takahashi H, Hano H, Jutabha P, Anzai N, Wempe MF and Endou H: Sex-associated difference in estrogen receptor $\beta$ expression in $\mathrm{N}$-methyl-N'-nitro-N-nitrosoguanidine-induced gastric cancers in rats. Comp Med 61: 412-418, 2011.

69. Choung RS and Locke GR III: Epidemiology of IBS. Gastroenterol Clin North Am 40: 1-10, 2011.

70. Heitkemper M, Jarrett M, Bond EF and Chang L: Impact of sex and gender on irritable bowel syndrome. Biol Res Nurs 5: 56-65, 2003 .

71. Longstreth GF and Wolde-Tsadik G: Irritable bowel-type symptoms in HMO examinees. Prevalence, demographics, and clinical correlates. Dig Dis Sci 38: 1581-1589, 1993.

72. Toner BB and Akman D: Gender role and irritable bowel syndrome: Literature review and hypothesis. Am J Gastroenterol 95: 11-16, 2000.

73. Heitkemper MM and Chang L: Do fluctuations in ovarian hormones affect gastrointestinal symptoms in women with irritable bowel syndrome? Gender Med 2(Suppl 6): 152-167, 2009.

74. Chaloner A and Greenwood-Van Meerveld B: Sexually dimorphic effects of unpredictable early life adversity on visceral pain behavior in a rodent model. J Pain 14: 270-280, 2013.

75. Cao DY, Ji Y, Tang B and Traub RJ: Estrogen receptor $\beta$ activation is antinociceptive in a model of visceral pain in the rat. J Pain 13: 685-694, 2012
76. Jacenik D, Cygankiewicz AI, Fichna J, Mokrowiecka A, Malecka-Panas E and Krajewska WM: Estrogen signaling deregulation related with local immune response modulation in irritable bowel syndrome. Mol Cell Endocrinol 471: 89-96, 2018.

77. Qin B, Dong L, Guo X, Jiang J, He Y, Wang X, Li L and Zhao J: Expression of $\mathrm{G}$ protein-coupled estrogen receptor in irritable bowel syndrome and its clinical significance. Int J Clin Exp Pathol 7: 2238-2246, 2014.

78. Zielinska M, Fichna J, Bashashati M, Habibi S, Sibaev A, Timmermans JP and Storr M: G protein-coupled estrogen receptor and estrogen receptor ligands regulate colonic motility and visceral pain. Neurogastroenterol Motil 29: 2017.

79. Mizoguchi A, Takeuchi T, Himuro H, Okada T and Mizoguchi E: Genetically engineered mouse models for studying inflammatory bowel disease. J Pathol 238: 205-219, 2016.

80. Xavier RJ and Podolsky DK: Unravelling the pathogenesis of inflammatory bowel disease. Nature 448: 427-434, 2007.

81. Molodecky NA, Soon IS, Rabi DM, Ghali WA, Ferris M, Chernoff G, Benchimol EI, Panaccione R, Ghosh S, Barkema HW and Kaplan GG: Increasing incidence and prevalence of the inflammatory bowel diseases with time, based on systematic review. Gastroenterology 142: 46-54.e42; quiz e30, 2012.

82. Cook LC, Hillhouse AE, Myles MH, Lubahn DB, Bryda EC, Davis JW and Franklin CL: The role of estrogen signaling in a mouse model of inflammatory bowel disease: A Helicobacter hepaticus model. PLoS One 9: e94209, 2014.

83. Barzi A, Lenz AM, Labonte MJ and Lenz HJ: Molecular pathways: Estrogen pathway in colorectal cancer. Clin Cancer Res 19: 5842-5848, 2013.

84. Principi M, Barone M, Pricci M, De Tullio N, Losurdo G, Ierardi E and Di Leo A: Ulcerative colitis: From inflammation to cancer. Do estrogen receptors have a role? World J Gastroenterol 20: 11496-11504, 2014

85. Pierdominici M, Maselli A, Varano B, Barbati C, Cesaro P, Spada C, Zullo A, Lorenzetti R, Rosati M, Rainaldi G, et al: Linking estrogen receptor $\beta$ expression with inflammatory bowel disease activity. Oncotarget 6: 40443-40451, 2015.

86. Armstrong CM, Allred KF, Weeks BR, Chapkin RS and Allred CD: Estradiol has differential effects on acute colonic inflammation in the presence and absence of estrogen receptor $\beta$ expression. Dig Dis Sci 62: 1977-1984, 2017.

87. Looijer-van Langen M, Hotte N, Dieleman LA, Albert E, Mulder $\mathrm{C}$ and Madsen KL: Estrogen receptor- $\beta$ signaling modulates epithelial barrier function. Am J Physiol Gastrointest Liver Physiol 300: G621-G626, 2011.

88. Saleiro D, Murillo G, Benya RV, Bissonnette M, Hart J and Mehta RG: Estrogen receptor- $\beta$ protects against colitis-associated neoplasia in mice. Int J Cancer 131: 2553-2561, 2012.

89. Bustos V, Nolan AM, Nijhuis A, Harvey H, Parker A, Poulsom R, McBryan J, Thomas W, Silver A and Harvey BJ: GPER mediates differential effects of estrogen on colon cancer cell proliferation and migration under normoxic and hypoxic conditions. Oncotarget 8: 84258-84275, 2017.

90. Konstantinopoulos PA, Kominea A, Vandoros G, Sykiotis GP, Andricopoulos P, Varakis I, Sotiropoulou-Bonikou G and Papavassiliou AG: Oestrogen receptor beta (ERbeta) is abundantly expressed in normal colonic mucosa, but declines in colon adenocarcinoma paralleling the tumour's dedifferentiation. Eur J Cancer 39: 1251-1258, 2003.

91. Delellis Henderson K, Duan L, Sullivan-Halley J, Ma H, Clarke CA, Neuhausen SL, Templeman C and Bernstein L: Menopausal hormone therapy use and risk of invasive colon cancer: The california teachers study. Am J Epidemiol 171: 415-425, 2010.

92. Manson JE, Chlebowski RT, Stefanick ML, Aragaki AK, Rossouw JE, Prentice RL, Anderson G, Howard BV Thomson CA, LaCroix AZ, et al: Menopausal hormone therapy and health outcomes during the intervention and extended poststopping phases of the Women's Health Initiative randomized trials. JAMA 310: 1353-1368, 2013.

93. Design of the Women's Health Initiative clinical trial and observational study. The Women's Health Initiative Study Group. Control Clin Trials 19: 61-109, 1998.

94. Calle EE, Miracle-McMahill HL, Thun MJ and Heath CW Jr: Estrogen replacement therapy and risk of fatal colon cancer in a prospective cohort of postmenopausal women. J Natl Cancer Inst 87: 517-523, 1995

95. Simon MS, Chlebowski RT, Wactawski-Wende J, Johnson KC, Muskovitz A, Kato I, Young A, Hubbell FA and Prentice RL: Estrogen plus progestin and colorectal cancer incidence and mortality. J Clin Oncol 30: 3983-3990, 2012. 